\title{
Rainfall Distribution Pattern of Progo Watershed in Observational and Empirical Method
}

\author{
Dinia Anggraheni ${ }^{1, *}$ and Dimas Gustoro ${ }^{1}$ \\ ${ }^{1}$ Department of Civil Engineering, Faculty of Civil Engineering and Planning, Islamic University of \\ Indonesia, Yogyakarta, Indonesia.
}

\begin{abstract}
Automatic Rainfall Recorder (ARR) has not been widely available in Indonesia, so data of rainfall is available in the form of daily rainfall. To know the pattern of rainfall distribution in a watershed, there are two methods, they are the observational and empirical method. the Observational Method can be done if it has automatic rainfall data minimal hourly-time in a long period. Meanwhile, the empirical method will be used when data is very limited. So in this research, there were two methods to develop the rainfall distribution pattern in Progo Watershed. The data were used by the observational method is from 2013 to 2015 . There were two empirical methods which are used namely Alternating Block Method (ABM) and Modified Mononobe Method. The results show that heavy rainfall in Progo watershed is dominated by 7-hourly rainfall distribution. The empirical rainfall distribution pattern that is more suitable with the observation method is Modified Mononobe method than ABM method.
\end{abstract}

\section{Introduction}

In hydrology, rainfall is one of the most important elements to be studied to design designflood. To analyze the design-flood, at least it requires the availability of rainfall data and topographic maps to determine the characteristics of the watershed. If rainfall data is available with minute duration and flow data, so a better analysis can be done. However, data availability in Indonesia is often lacking and limited. There are still many rainfall stations in Indonesia using the daily observation. Therefore, rainfall distribution patterns can be made by empirical methods.

There are many empirical methods to generate rainfall distribution pattern as example Alternating Block Method (ABM), Tadashi Tanimoto Method, Triangular Hyetograph Method (THM), and Modified Mononobe Method.

Asfa, Handayani, \& Hendri (2014) analyzed rainfall data to generate rainfall distribution model using the Alternating Block Method (ABM), Modified Mononobe, and Tadashi Tanimoto. The study used data from rainfall stations in Pasar Kampar. The research shows that rainfall in Pasar Kampar Station was dominated by three-hour rainfall events. The result shows that the rainfall distribution of ABM model gave out the largest

\footnotetext{
*Corresponding author: dinia.anggraheni@uii.ac.id
} 
deviation for three to seven hours, but Tadashi Tanimoto model gave out the smallest deviation for eight hours [1].

Salem, Sumarauw, \& Wuisan (2016) analyzed rainfall hourly distribution pattern in Manado City and its around. Rainfall data was used for 2010 to 2015 in three stations. Rainfall distribution was dominated by $8-10$ hours and follows the third shape of rainfall distribution of Johannes Brummer. It shows that rainfall has the downward trend with the monotonous intensity [2].

Dominant duration of rainfall is the one that important to analyze the rainfall characteristic. The rainfall characteristic is known while analyzing the transformation process of rainfall to runoff model. Sofia (2016) also analyzed the dominant duration of rainfall in Merapi Volcano Area to identify the rainfall that caused debris runoff while eruption is occurring. From the 20 rainfall station, the dominant duration of rainfall is 2 to 7 hours. In average, the dominant duration of heavy rainfall has an inclining trend in the first hour and decline in the next hour [3].

Brotowiryatmo (2016) reviewed rainfall hourly distribution on the island of Java. One of the possible uncertain variables for the analysis is the rainfall hourly distribution (RHD). Up the present days, there are no RHD available which gives an estimate of the catchment RHD with relatively high accuracy for this area. Due to the lack of variable, the common RHD applied by the hydrologist is one contained in the textbook such as the Alternating Block Method (ABM) (Chow, et, al, 1998) and the Tadashi Tanimoto's method (Mutia (2011) and Lauw (2012)). The study concludes in the case of no RHD data, equation generated by Mutia (2011) and Lauw (2012) can be used instead. Therefore, any catchment there will be a special characteristic of RHD, but a general pattern can be obtained by relatively adequate accuracy [4].

Based on the previous studies about rainfall distribution, the aims of this research are to know the rainfall characteristic of Progo Watershed by dominant duration, to develop a pattern of rainfall distribution, and to obtain the deviation of the observational and empirical method.

\section{Theoretical Basis}

\subsection{Rainfall Characteristics}

Understanding the rainfall conditions are required by the effective hazard management. Godt, Baum, \& Chleborad (2006) analyzed rainfall characteristics in understanding shallow landsliding in Seattle, Washington, USA. They combined a simple water balance to estimate the antecedent moisture conditions of hillslope materials and a rainfall intensityduration threshold to identify the period when shallow landsliding can be expected. The result of the study is a hypothetical landslide warning system [5].

Rainfall characteristic has a variety of spatial and temporal. Chen \& Chen (2003) analyzed the rainfall characteristics of Taiwan. Because of the location of Taiwan, its climate strongly affected by the East Asian monsoons. The result studies show that the horizontal distribution of climatological rainfall pattern for different rainfall regimes strongly depends on the direction of the low-level prevailing flow with much higher rainfall on the windward side. Furthermore, the seasonal variations in rainfall amount and type also depend on the thermodynamic stratification and the availability of moisture [6]. 


\subsection{Rainfall Intensity}

Suroso (2006) explained that rainfall intensity is a depth of rainfall over the time where the rainwater is being concentrated in $\mathrm{mm} /$ hour unit [7]. World Meteorological Organization (WMO) in Triatmodjo (2008) classified the International Standart of Rainfall Intensity, they are followed in Table 1 below [8].

Table 1. Classification of Rainfall Intensity by WMO International Standard

\begin{tabular}{|c|c|}
\hline Rainfall Criteria & Rainfall Intensity \\
\hline Very Light & $<5.0 \mathrm{~mm}$ \\
\hline Light & $5.0-20 \mathrm{~mm}$ \\
\hline Normal & $20-50 \mathrm{~mm}$ \\
\hline Heavy & $50-100 \mathrm{~mm}$ \\
\hline Extreme & $>100 \mathrm{~mm}$ \\
\hline
\end{tabular}

In this research, to calculate the rainfall intensity is used Mononobe Formula (Triatmodjo, 2008) as follows [8].

$$
R_{T}=\frac{R_{24}}{24}\left(\frac{24}{T}\right)^{\frac{2}{3}}
$$

Where $R_{T}$ is the rainfall intensity ( $\mathrm{mm} /$ hour), $R_{24}$ is the maximum rainfall depth in a day (mm), and $T$ is the duration of rainfall (hour).

\subsection{Rainfall Distribution Pattern}

Rainfall distribution is different depending on the time and an area. The pattern of rainfall distribution has the variety of shape or histogram. The shapes are like a bell, down-ladder, up-ladder, steady line, or unsteady line. it is caused by the different number of rainfall distribution per hour (Thessalonika, Handayani, \& Fauzi, 2018) [9].

\subsubsection{Alternating Block Method (ABM)}

The depth of rainfall is obtained by multiplication between the rainfall intensity and the duration. The difference of the rainfall depth in order is the increase of the depth rainfall by the time interval $(\Delta \mathrm{t})$. Then, the rainfall depth is organized in order by putting the maximum rainfall in the center of hyetograph, then it is followed the next rainfall depth in the right and left. The hyetograph of ABM Method is shown in Fig. 1 below. 


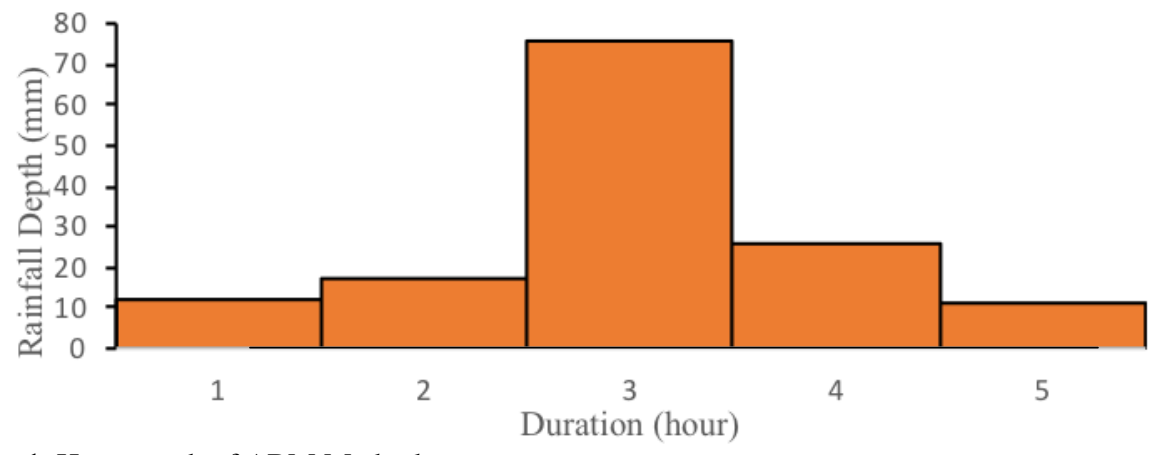

Fig. 1. Hyetograph of ABM Method

\subsubsection{Modified Mononobe}

Modified Mononobe is one of the methods to generate rainfall distribution pattern which is the development of Mononobe method. The formula is as follow.

$$
I_{P}^{T}=\frac{R_{24}}{t c}\left(\frac{t c}{T}\right)^{\frac{2}{3}}
$$

Where $I_{P}^{T}$ is the rainfall intensity with the return period $P$ for the duration $t(\mathrm{~mm} /$ hour), $R_{24}$ is the rainfall depth in a day ( $\mathrm{mm}$ ) with the return period $P, t c$ is the concentration-time (hour).

The concentration-time $(t c)$ is the time that needed to flow water from the furthest point to the control point, downstream. tc was calculated by Australian Rainfall-Runoff (ARR) Formula in Kibar (2015) as follow [10].

$$
t c=0.76 A^{0.38}
$$

Where $A$ is the area of the watershed $\left(\mathrm{km}^{2}\right)$.

\subsection{Frequency Analysis of Rainfall}

Frequency analysis is a way of determining the design-rainfall or discharge of a watershed based on rainfall or discharge data of previous years. The rainfall or discharge data follows one of the known distributions in Indonesia. They are Normal Distribution, Normal Log Distribution, Gumbel, Pearson and Log Pearson type III.

To determine the type of distribution, the statistical parameters were calculated. They are mean, standard deviation, the coefficient of variation, kurtosis coefficient and skewness coefficient (Triatmodjo, 2008) [8].

Rainfall or discharge design is calculated by the following formula:

$$
X_{T}=\bar{X}+K_{T} \cdot S
$$

Where $X_{T}$ is the design-rainfall or discharge with the return period $\mathrm{T}, \bar{X}$ is mean of rainfall or discharge data, $K_{T}$ is the frequency coefficient of the return period T, and $S$ is the standard deviation. 


\section{Methodology}

The study area is the Progo Watershed. The data that used was obtained from Kalibawang, Kenteng, Sapon, Sanden, Kalijoho, Pajangan, Seyegan, and Godean Station during 20132015. Then, the rainfall data was made in a group of duration in 2-8 hours. Then, the dominant rainfall was analyzed to understand the rainfall characteristic and made in a group by rainfall criteria, light, and heavy rainfall. Then, it was analyzed to develop the rainfall distribution pattern. In addition, the rainfall distribution pattern was also developed by the empirical method by ABM and Modified Mononobe Method. Therefore, the next step was the frequency analysis of rainfall to design the rainfall during the return period. Finally, the rainfall distribution pattern by observational and empirical method was analyzed to obtain the deviation or the accuracy.

\section{Data Analysis}

The rainfall data was made in the group by rainfall criteria. The recapitulation of the light (the depth $<50 \mathrm{~mm}$ ) and the heavy rainfall (the depth $>50 \mathrm{~mm}$ ) group is shown in Table 2 .

Table 2. Identification of Rainfall Frequency, Under and Over The Rainfall Depth of $50 \mathrm{~mm}$

\begin{tabular}{|c|c|c|c|c|c|c|c|c|}
\hline Duration (hour) & $\mathbf{2}$ & $\mathbf{3}$ & $\mathbf{4}$ & $\mathbf{5}$ & $\mathbf{6}$ & $\mathbf{7}$ & $\mathbf{8}$ & Total \\
\hline Freq. of Rainfall $<\mathbf{5 0} \mathbf{~ m m}$ & 390 & 222 & 127 & 74 & 56 & 29 & 22 & 920 \\
Freq. of Rainfall $>\mathbf{5 0} \mathbf{~ m m}$ & 4 & 4 & 10 & 5 & 2 & 11 & 3 & 39 \\
\hline
\end{tabular}

The rainfall distribution that calculated by the observational method is shown in Table 3 .

Table 3. Recapitulation of Rainfall Distribution by Observation Method

\begin{tabular}{|c|c|c|c|c|c|c|c|c|}
\hline \multirow{2}{*}{ Duration } & \multicolumn{7}{|c|}{ Rainfall (\%) } \\
\cline { 2 - 9 } & $\mathbf{1}$ & $\mathbf{2}$ & $\mathbf{3}$ & $\mathbf{4}$ & $\mathbf{5}$ & $\mathbf{6}$ & $\mathbf{7}$ & $\mathbf{8}$ \\
\hline $\mathbf{2}$ & 64.37 & 35.63 & & & & & & \\
\hline Cumulative & 64.37 & 100.00 & & & & & & \\
\hline $\mathbf{3}$ & 69.34 & 23.12 & 7.54 & & & & & \\
\hline Cumulative & 69.34 & 92.46 & 100.00 & & & & & \\
\hline $\mathbf{4}$ & 45.42 & 30.45 & 20.33 & 3.81 & & & & \\
\hline Cumulative & 45.42 & 75.86 & 96.19 & 100.00 & & & & \\
\hline $\mathbf{5}$ & 34.45 & 20.42 & 18.12 & 25.43 & 1.57 & & & \\
\hline Cumulative & 34.45 & 54.88 & 73.00 & 98.43 & 100.00 & & & \\
\hline $\mathbf{6}$ & 15.34 & 69.57 & 10.56 & 3.29 & 0.81 & 0.43 & & \\
\hline Cumulative & 15.34 & 84.91 & 95.47 & 98.76 & 99.57 & 100.00 & & \\
\hline $\mathbf{7}$ & 27.62 & 32.07 & 8.25 & 19.89 & 6.24 & 3.93 & 2.00 & \\
\hline Cumulative & 27.62 & 59.69 & 67.94 & 87.83 & 94.07 & 98.00 & 100.00 & \\
\hline $\mathbf{8}$ & 39.34 & 33.91 & 9.18 & 5.01 & 8.90 & 2.01 & 1.03 & 0.61 \\
\hline Cumulative & 39.34 & 73.26 & 82.44 & 87.45 & 96.35 & 98.36 & 99.39 & 100.00 \\
\hline
\end{tabular}


The result of the observational rainfall distribution that shown in Table 3 are the average of rainfall distribution for each duration.

The frequency analysis indicated that the best distribution of rainfall data was Normal Distribution. The result of design-rainfall is as follow in Table 4.

Table 4. The Design-Rainfall $\left(X_{T}\right)$ with The Return Period $(T)$

\begin{tabular}{|c|c|c|c|c|c|c|c|c|}
\hline $\boldsymbol{T}($ year) & 2 & 5 & 10 & 20 & 25 & 50 & 100 & 200 \\
\hline $\boldsymbol{X}_{\boldsymbol{T}}(\mathbf{m m})$ & 73.51 & 101.54 & 116.20 & 128.31 & 131.84 & 141.94 & 151.02 & 159.33 \\
\hline
\end{tabular}

Then, the concentration-time $(t c)$ was calculated by ARR Method where needed the area of Progo Watershed, $2421.41 \mathrm{~km}^{2}$ (Ministry of Public Works and Populace Housing (PUPR), 2010) [11]. The number of the concentration-time is 14.68 hours.

Because of little difference trend while the design-rainfall applied to develop the rainfall distribution pattern using the empirical method, so the return period of the design rainfall that used was 2 year $(73.51 \mathrm{~mm})$.

The patterns of rainfall distribution which generated by the observational method, the ABM method, and Modified Mononobe method are shown in Fig. 2.
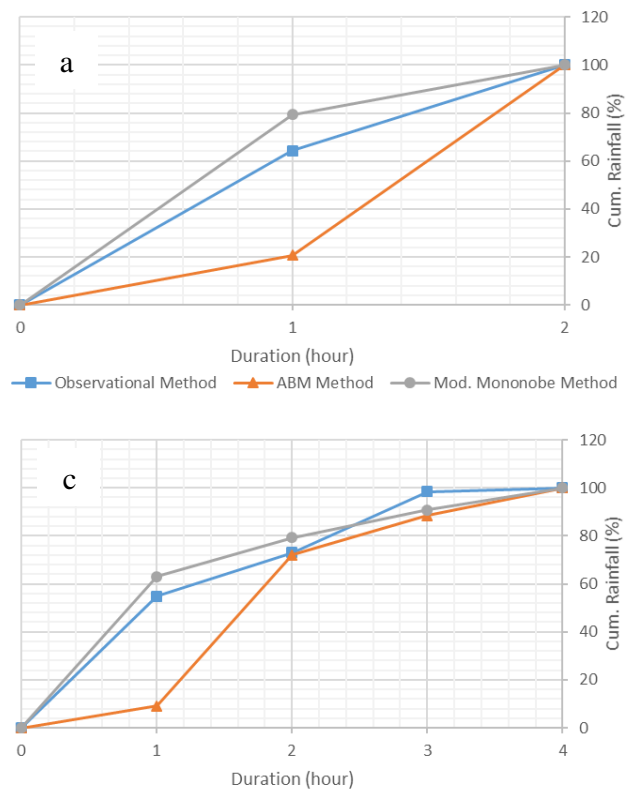

$\rightarrow$ - Observational Method $\rightarrow$ ABM Method $\rightarrow$ Mod. Mononobe Method

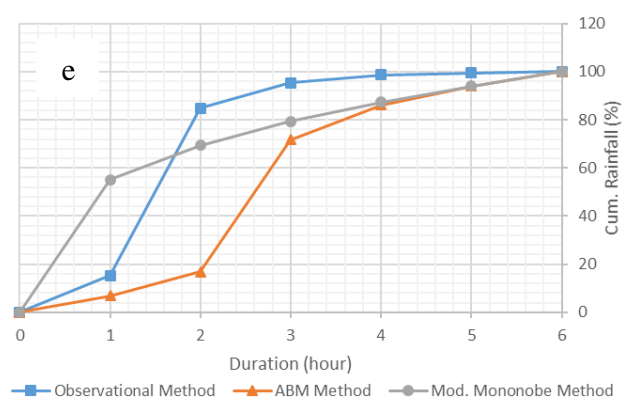

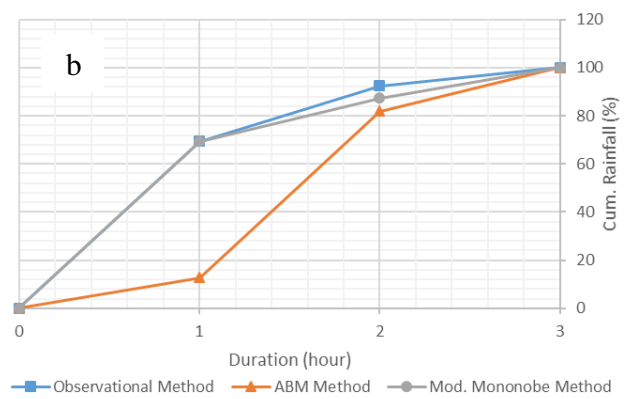

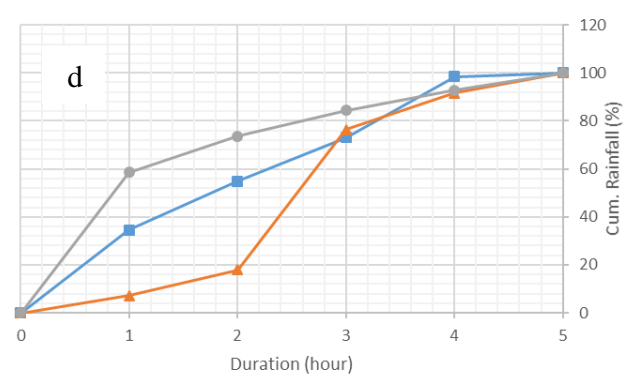

$\rightarrow$ Observational Method $\rightarrow$ ABM Method $\rightarrow$ Mod. Mononobe Method

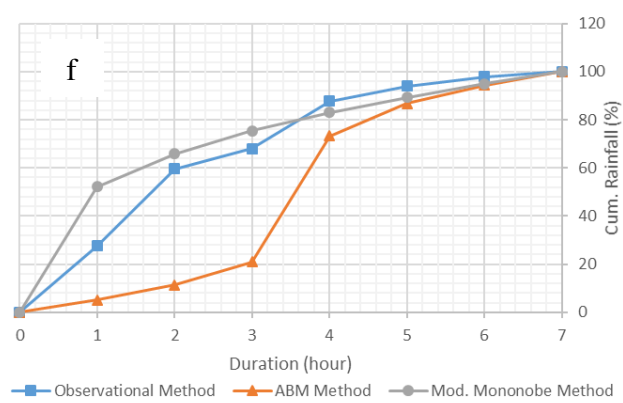




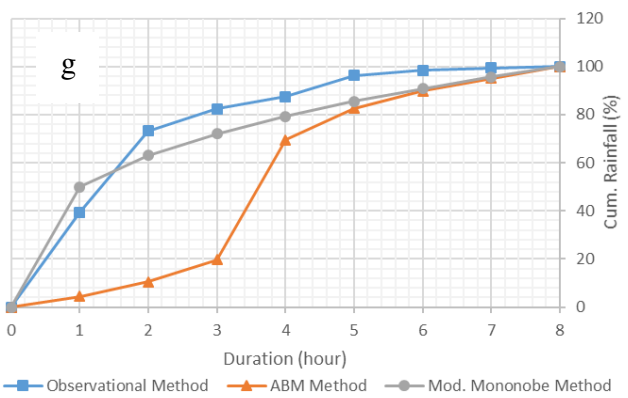

Fig. 2. The Rainfall Distribution Pattern Using Observational Method, ABM Method, and Modified Mononobe Method in Duration of 2-8 Hours, respectively (a)-(g)

The Rainfall Distribution Pattern that resulted by the observational method as shown in Table 3 then it was compared with the empirical method i.e. ABM Method and Modified Mononobe Method. Fig. 2 shows the deviation of the pattern in each specific duration. It is discussed in section 4 (Result and Discussions).

The average deviation of the patterns using the empirical method to the observational method is as follow in Table 5 .

Table 5. The Average Deviation of The Pattern Using Empirical Method

\begin{tabular}{|c|c|c|}
\hline \multirow{2}{*}{ Duration (hour) } & \multicolumn{2}{|c|}{ Deviation of The Empirical Method (\%) } \\
\cline { 2 - 3 } & ABM & M. Mononobe \\
\hline $\mathbf{2}$ & $-68 \%$ & $23 \%$ \\
\hline $\mathbf{3}$ & $-47 \%$ & $-3 \%$ \\
\hline $\mathbf{4}$ & $-32 \%$ & $5 \%$ \\
\hline $\mathbf{5}$ & $-37 \%$ & $28 \%$ \\
\hline $\mathbf{6}$ & $-36 \%$ & $41 \%$ \\
\hline $\mathbf{7}$ & $-43 \%$ & $16 \%$ \\
\hline $\mathbf{8}$ & $-43 \%$ & $-4 \%$ \\
\hline
\end{tabular}

The negative number shown in Table 5 means the tren of the rainfall distribution pattern using the observational method is smaller than using the empirical method, and conversely for the positive number.

\section{Result and Discussions}

The rainfall characteristics of Progo Watershed is shown clearly based on Table 2. Mostly, during 2013-2015, the characteristics of the rainfall was light rainfall. They are 920 events of the depth rainfall under $50 \mathrm{~mm}$, with the dominant rainfall duration is 2 hours. But, heavy rainfall is important to be understood, because it often causes events of flood runoff. There are 39 events explained heavy rainfall, with the dominant rainfall duration is 7 hours.

The observational method is shown that the patterns of rainfall distribution of Progo Watershed during 2013-2015 almost have a downward trend. The intensity of rainfall is highest in the first hour and a decrease in the next hours, except for the duration of 7 hours. It has the highest depth in the second hour, and a decrease in the next hours. 
If it was compared using the empirical method to develop the rainfall distribution patterns, there are deviations. Fig. 2 shows that overall, the pattern using the observational method inclined Modified Mononobe Method with little deviation or insignificant differences, better than using ABM Method. Although to develop the rainfall distribution pattern using Modified Mononobe is better, but it suitable for the duration of 3,4,8 hours with the average deviation is under $10 \%$ (see Table 5 ).

\section{Conclusions and Recommendations}

From this study, we concluded that:

- the rainfall characteristics of Progo Watershed was a light rainfall over the period during 2013-2015. The characteristic of rainfall that causing a flood is heavy rainfall. The dominant duration of heavy rainfall is 7 hours, and

- if there is no automatic rainfall data, using Modified Mononobe as the empirical method to develop the rainfall distribution pattern is more suitable than using ABM method.

For the better next research, we recommend that:

- the longer period of data generate the better result to more understand the rainfall characteristics of Progo Watershed minimum ten years,

- the other empirical method usually used in Indonesia can be used such as Triangular Hyetograph Method (THM) and Tadashi Tanimoto.

- the research can be continued with calculating of the flood hydrograph.

\section{References}

1. Asfa, A. F., Handayani, Y. L., \& Hendri, A. Rainfall Hourly Distribution Pattern in Pasar Kampar Rainfall Station (Indonesian). Jom FTEKNIK, 1(2), 1-5, (2014)

2. Salem, H. P., Sumarauw, J. F., \& Wuisan, E. M. Rainfall Hourly Distribution in Manado City and Its Surrounding (Indonesian). Jurnal Sipil Statik, 4(3), 203-210, (2016)

3. Sofia, D. A. Analysis of Dominant Rainfall Duration and Rainfall Hourly Duration in Merapi Volcano Area (Indonesian). Jurnal Teknologi Rekayasa (JTERA), 1(1), 7-14, (2016)

4. Brotowiryatmo, S. Review of Rainfall Hourly Distribution on the Island of Java. Journal of The Civil Engineering Forum, 2(1), 33-38, (2016)

5. Godt, J. W., Baum, R. L., \& Chleborad, A. F. Rainfall Characteristic for Shallow Landsliding in Seattle, Washington, USA. Earth Surface Processes and Landforms, 31, 97-100. doi:I0.I002/esp.1237, (2006)

6. Chen, C.-S., \& Chen, Y.-L. The Rainfall Characteristics of Taiwan. American Meteorological Society, 1323-1341, (2003)

7. Suroso. (2006). Analysis of Rainfall to Generate The Intensity-Duration-Frequency (IDF) Curve in The Flood Prone Area of Banyumas Regency (Indonesian). Jurnal Teknik Sipil, 03(01), (2006)

8. Triatmodjo, B. Applied Hydrology (Indonesian). Yogyakarta: Beta Offset, (2008)

9. Thessalonika, Handayani, Y. L., \& Fauzi, M. The Shape of Rainfall Hourly Distribution of Kampar Regency (Indonesian) According to Satelite Data (Indonesian). Jom FTEKNIK, 5(1), 1-8, (2018)

10. Kibar, Yusuf. Analysis of Short Duration Rainfall Characteristic and Its Impact on Flood Design (Indonesian). Jurusan Teknik Sipil dan Lingkungan, Fakultas Teknik, Universitas Gadjah Mada Yogyakarta, (2015) 
11. Ministry of Public Works and Menteri Pekerjaan Umum, Keputusan Menteri Pekerjaan Umum No. 590/KPTS/M/2010 Tentang Pola Pengelolaan Sumber Daya Air Wilayah Sungai Progo - Opak - Serang, (2010) 